\title{
Study on the Interaction between the Genotype and the Exogenous Factors and their Influence on Rooting of Gloxinia Cuttings
}

\author{
Erzsebet BUTA ${ }^{1)}$, Maria CANTOR ${ }^{1)}$, Denisa $\mathrm{HORT}^{11}$ and Radu SESTRAŞ ${ }^{1 *}$ ) \\ ${ }^{1)}$ Department of Horticulture and Landscaping. University of Agricultural Sciences and Veterinary \\ Medicine, Cluj-Napoca, Romania. \\ ${ }^{*}$ Corresponding author, e-mail:_rsestras@yahoo.co.uk
}

Bulletin UASVM Horticulture 71(2) / 2014

Print ISSN 1843-5254, Electronic ISSN 1843-5394

DOI:10.15835/buasvmcn-hort:10624

\begin{abstract}
Obtaining valuablegenotypes in terms of ornamental purposes and the improvement of the decorative plants genetic fund are an ongoing concern to breeders across all regions of the world. Genotypes with particular features and trait characteristics for breeding which can lend themselves to efficient and rapid propagation methods are of great interest. In the experiments conducted in this paper the following objectives were established: examining intraspecific variability in Gloxinia plant, the study of vegetative propagation through leaves cuttings based on the cutting type; the study of the degree of rooting cuttings; the influence of the substrate on rooting cuttings; the analysis on the interaction between the genotype and the growth factors. Three Gloxinia genotypes were tested (A, B C) and four rooting substrates: peat, perlite, peat + perlite, peat + perlite + manure (ratio 1:1:1). The research carried out showed that the rooting period of Gloxinia leaves cuttings varied depending on the substrate used between 29 and 38 days. The studies in the genus were differently influenced by the rooting environment, but also by the cutting type that was made. The best results in terms of rooting expressed by length of the root system were obtained in the B genotype in the substrate made of peat + perlite + manure. It has been noticed a significant positive interaction between the temperature of the rooting substrate and the length of the roots in the three genotypes studied. Negative correlation has been noticed between the size of the root system and the light intensity depending on the age of cuttings used.
\end{abstract}

Keywords: Sinningia, multiplication, peat, perlite, sand

\section{INTRODUCTION}

The Gesneriaceae family comprises about 250 genera and about 3200 species worldwide of which the most common are: Achimenes, Aeschynanthus, Alsobia, Chirita, Columnea, Episcia, Gesneria, Gloxinella, Kohleria, Nematanthus, Petrocosmea, Saintpaulia, Gloxinia, Smithiantha, Streptocarpus (Cantor, 2008).

The first Gloxinia plants were introduced to cultivation by the famous plant collector William Lobb. The correct scientific name of the species is Sinningia named after Wilhelm Sinning (17941874), the German horticulturist who was the Garden Supervisor of Bonn University's botanical garden. The most used botanical name by cultivators is Gloxinia given by Peter Gloxin, a German physician and botanical writer from Colmar (Germany) in 1785. The genus includes 12 species originating from tropical America. Sinningia speciosa native to Brazil is the basic species from which derive the hybrids traded today (Cervantes, 2010). The species is grown as an indoor plant, but can also be used as an outdoor plant during summer. Gloxinia speciosa is interest because of the content of anthraquinones and ethylcyclohexane isolated tuber and leaves (Verdan et al., 2009).

Gloxinia speciosa Benth. Et. Hook is a perennial plant that forms a thick large tuber under the soil 
surface (Şelaru, 2004; Cantor, 2008). This indoor species decorates by itslargecampanulatediversely colored flowers which can be simple or double. For blooming, it requires a daytime temperature of 16 to $21^{\circ} \mathrm{C}$ and a nighttime temperature of $18^{\circ} \mathrm{C}$; it can also develop at temperatures up to $30-35^{\circ} \mathrm{C}$ provided that the relative humidity in the area of growth is high and the direct exposure of plant to the sun is avoided (Şelaru, 2004, 2006, Cantor, 2008). The underground stem requires during the rest period an optimal temperature of $4-6^{\circ} \mathrm{C}$ (Cervantes, 2010).

The studied species does not like direct sunlight and should not be exposed to it (leaves curl under on the edges) and has a relatively high degree of tolerance to shade. Too much shade can cause buds to drop. The best exposure for Gloxinia is southwest with the possibility of shading during the hours of insolation (Cantor, 2008; Şelaru, 2004; Toma, 2009). The optimum temperature for rooting cuttings is $22-25^{\circ} \mathrm{C}$ and the relative humidity of $80-90 \%$ (Şelaru, 2004, 2006).

For successful cultivation of Gloxinia the substrate must contain peat, perlite and compost in equal ratios (Cervantes, 2010) and it must be slightly acidic (pH 6 to 6.5).

Şelaru (2006) mentions that a mixture of 3 parts leaf compost, 1 part mature manure and 1-2 $\mathrm{kg} / \mathrm{m}^{3}$ limestone, determine a better plant growth and development.

Procter (1986) cited by Buta et al., 2011 recommends a substrate of culture that includes: clayey ground, peat, humus and sand (in a ratio of 1: 1: 1: 1), 3 parts of the hoof meal, 3 parts of superphosphate and $1 \frac{1}{2}$ parts of potassium sulfate, $28 \mathrm{~g}$ of bone meal powder and $28 \mathrm{~g}$ of chalk.

Gloxinia is propagated from seed, tubers, leaf or stem cuttings (in the early summer). For this purpose the basal leaves with thicker leave petioles are harvested (Draghia and Chelariu, 2011).

\section{MATERIALS AND METHODS}

The experiments on monitoring the valuable Gloxinia genotypes and the exogenous factors and their influence on the rooting of Gloxinia cuttings were conducted in the period 2013-2014 within the greenhouse of the Floriculture Department of the University of Agricultural Sciences and Veterinary Medicine Cluj-Napoca.

The purpose of this study was to determine the interaction between the genotype and the exo- genous factors and their influence on the rooting of Gloxinia cuttings, but also to improve the genetic fund of ornamental plants with new genotypes in our country. In order to achieve the proposed goal, the following objectives were established: the study of vegetative propagation through leaves cuttings based on the cutting type; the study of the degree of rooting cuttings; the influence of the substrate on rooting cuttings; the analysis on the interaction between the genotype and the growth factors (substrate temperature, light intensity of growing space).

Three Gloxinia genotypes were tested (A, B, C), two types of cuttings (harvested at 30 days and 50 days after onset) and four rooting substrates: peat $(\mathrm{P})$, perlite $(\mathrm{Pe})$, peat + perlite $(\mathrm{P}+\mathrm{Pe})$, peat + perlite + manure $(\mathrm{P}+\mathrm{Pe}+\mathrm{M})$ (ratio 1:1:1). The combined analyzed factors resulted in 24 experimental variants which were randomly assigned in three replicates. There were made 20 cuttings for each experimental variant. Peat has a pH of about 5,02. The perlite particle size is about $0,2 \mathrm{~mm}$.

The assessment of genotype and substrate influence on rooting cuttings of Gloxinia was carried out through the prism of the size of the root system. The quality of rooted cuttings is expressed by the number and the size of the root system and it is heavily influenced by the composition of the mixture used.

The external factors (temperature, substrate and light intensity) have a high influence on the degree of rooting cuttings and their development. Therefore, in the present paper conclusive data was collected and interpreted with regards to the conditions of Gloxinia rooting cuttings. Thus, it was determined, over a period of 15 days, the rooting substrate temperature, at 12 o'clock. For the same period of 15 days, it was registered data on the light intensity in the rooting environment (at 12 o'clock). The average temperature of propagation environment was $23.5^{\circ} \mathrm{C}$ and the light intensity reached an average of 37.815 lux.

After preparing the cuttings were treated with $0.1 \%$ Previcur Energy (s.a. fosetyl $310 \mathrm{~g} / \mathrm{l}+$ propamocarb $530 \mathrm{~g} / \mathrm{l}$ ), then they were planted in the 4 rooting substrates shortly after the treatment was applied.

The data on the size of the root system was conducted 38 days after the cuttings, although the first roots developed after 29 days from the cuttings. The rooting percentages for the diffe- 
rent treatments were: peat $82 \%$, perlite $87 \%$, peat+perlite $79 \%$ and peat+perlite+manure $93 \%$.

The control was the average experience. The recorded data was statistically interpreted with the variance analysis, worked out as average values per variant. The correlations were performed using Microsoft Excel.

\section{RESULTS AND DISCUSSION}

The unilateral influence of studied varieties on the size of the root system in the genus Gloxinia is shown in Table 1. It is noticed, as a result of the measurements undertaken, that of the three genotypes studied, B genotype shows significant positive differences and statistically ensured. To this, the size of the roots exceeds the control with $0.65 \mathrm{~cm}$.

Table 2 presents data on the unilateral influence of age-sided leaf cuttings on the size of the root system in the genus Gloxinia. Compared with the average experience, the values statistically analyzed for the studied character are recorded for cuttings developed after 50 days. The differences in size were of $1.04 \mathrm{~cm}$, positively and highly significant.

Tab. 1. Unilateral influence of studied genotypes on the length of the root system of Gloxinia

\begin{tabular}{|c|c|c|c|c|}
\hline \multirow{2}{*}{ Studied genotypes } & \multicolumn{2}{|c|}{ Length of the root } & \multirow{2}{*}{$\pm \mathrm{D}(\mathrm{cm})$} & \multirow{2}{*}{ Significatior } \\
\hline & Absolute $(\mathrm{cm})$ & Relative (\%) & & \\
\hline A & 7.75 & 92.3 & -0.71 & NS \\
\hline $\mathrm{B}$ & 9.11 & 108.6 & 0.65 & $*$ \\
\hline $\mathrm{C}$ & 8.54 & 100.9 & -0.08 & - \\
\hline Mean of experience (C) & 8.46 & 100.0 & 00.0 & - \\
\hline DL (p 5\%) & & & 0.58 & \\
\hline DL (p 1\%) & & & 1.03 & \\
\hline DL (p 0,1\%) & & & 2.46 & \\
\hline
\end{tabular}

Tab. 2. Unilateral influence age-sided leaf cuttings on the length of the root system of Gloxinia

\begin{tabular}{lcccc}
\hline \multirow{2}{*}{ Age-sided leaves } & \multicolumn{2}{c}{ Length of the root } & \multirow{2}{*}{ \pm (cm) } & \multirow{2}{*}{ Signification } \\
\cline { 2 - 3 } & Absolute $(\mathrm{cm})$ & Relative $(\%)$ & & \\
\hline 30 days & 7.43 & 87.7 & -1.03 & 000 \\
\hline 50 days & 9.50 & 112.2 & 1.04 & $* * *$ \\
\hline Mean of experience (C) & 8.46 & 100.0 & 00.0 & - \\
\hline DL (p 5\%) & & & 0.13 & \\
DL (p 1\%) & & & 0.24 & \\
DL (p 0,1\%) & & & 0.54 &
\end{tabular}

Tab. 3. Unilateral influence of rooting substrate (media) on the length of the root system of Gloxinia

\begin{tabular}{ccccc}
\hline \multirow{2}{*}{ Rooting media } & \multicolumn{2}{c}{ Length of the root } & & \\
\cline { 2 - 3 } & $\begin{array}{c}\text { Absolute } \\
(\mathrm{cm})\end{array}$ & $\begin{array}{c}\text { Relative } \\
(\%)\end{array}$ & $\pm \mathrm{D}(\mathrm{cm})$ & Signification \\
\hline Peat & 8.04 & 101.9 & -0.42 & - \\
\hline Perlite (Pe) & 8.34 & 105.8 & -0.12 & - \\
\hline Peat + perlite - P+Pe & 8.40 & 106.6 & -0.06 & - \\
\hline Peat + perlite + manure - P+Pe+M & 9.09 & 107.4 & 0.63 & $*$ \\
\hline Mean of experience (C) & 8.46 & 100.0 & 00.0 & - \\
\hline DL (p 5\%) & & & 0.62 & \\
DL (p 1\%) & & & 0.85 & \\
DL (p 0,1\%) & & & 1.15 &
\end{tabular}


Analyzing the unilateral influence of the rooting substrate on the size of the root system in the genus Gloxinia it was found that the mixture of peat + perlite + manure (1: 1: 1) determines a high degree of rooting. The differences in size for this genus are $0.63 \mathrm{~cm}$, positively and highly significant and statistically assure (Table 3). The substrates of peat and perlite, used alone and also in combination are not favorable to Gloxinia cultivars.

The data regarding the combined influence of experimental factors (G-genotype, cutting age - V, rooting substrate - S) highlight a series of favorable results (Table 4). The best combination is between $B$ genotype $x 50$ days $x$ perlite, which generated a difference in the length of the root system of $2.1 \mathrm{~cm}$.
This difference is significant and statistically assured. Similar values were recorded in the following four combinations: B genotype $\mathrm{x} 50$ days $\mathrm{x}$ peat + perlite + manure, $B$ genotype $x 50$ days $x$ peat + perlite, genotype $\mathrm{C} \times 50$ days $\mathrm{x}$ peat + perlite, genotype $\mathrm{C} \times 50$ days $\mathrm{x}$ peat + perlite + manure. Only one favorable combination was registered (A genotype $\mathrm{x} 30$ days $\mathrm{x}$ peat + perlite + manure) in the case where a young cutting was used (30 days) in A genotype which determined a positively significant difference $(1.55 \mathrm{~cm})$.

It has been noticed a significant positive interaction between the temperature of the rooting substrate and the length of the roots in the three genotypes studied. The data in Figure 1 presents the young

Tab. 4. Combined influence of experimental (genotype -G, days old cuttings - D, rooting substrate - S) on the length of the root system of Gloxinia

\begin{tabular}{|c|c|c|c|c|}
\hline \multirow{2}{*}{$\begin{array}{l}\text { Experimental variants } \\
(G \times D \times S)\end{array}$} & \multicolumn{2}{|c|}{ Length of the root } & \multirow[b]{2}{*}{$\pm \mathrm{D}(\mathrm{cm})$} & \multirow[b]{2}{*}{ Signification } \\
\hline & $\begin{array}{l}\text { Absolute } \\
\text { (cm) }\end{array}$ & $\begin{array}{l}\text { Relative } \\
(\%)\end{array}$ & & \\
\hline A x 30 days old $\times \mathrm{P}$ & 6.65 & 23.4 & -2.3 & 00 \\
\hline $\mathrm{B} \times 30$ days old $\times \mathrm{P}$ & 6.90 & 31.5 & -2.05 & 0 \\
\hline $\mathrm{C} \times 30$ days old $\mathrm{x} \mathrm{P}$ & 7.50 & 16.8 & -1.45 & 0 \\
\hline A x 30 days old $\times \mathrm{Pe}$ & 7.65 & 20.1 & -1.3 & 0 \\
\hline $\mathrm{B} \times 30$ days old $\times \mathrm{Pe}$ & 7.30 & 23.6 & -1.65 & 0 \\
\hline $\mathrm{C}$ x 30 days old $\times \mathrm{Pe}$ & 6.90 & 29.0 & -2.05 & 0 \\
\hline $\mathrm{A} \times 30$ days old $\times \mathrm{P}+\mathrm{Pe}$ & 6.65 & 37.7 & -2.3 & 00 \\
\hline $\mathrm{B} \times 30$ days old $\times \mathrm{P}+\mathrm{Pe}$ & 7.30 & 50.8 & -1.65 & 0 \\
\hline $\mathrm{C} \times 30$ days old $\times \mathrm{P}+\mathrm{Pe}$ & 7.35 & 62.3 & -1.6 & 0 \\
\hline A $\times 30$ days old $\times P+P e+M$ & 7.40 & 75.9 & 1.55 & $*$ \\
\hline $\mathrm{B} \times 30$ days old $\times \mathrm{P}+\mathrm{Pe}+\mathrm{M}$ & 9.85 & 91.8 & 0.90 & - \\
\hline $\mathrm{C} \times 30$ days old $\times \mathrm{P}+\mathrm{Pe}+\mathrm{M}$ & 7.75 & 83.5 & -1.2 & 0 \\
\hline A x 50 days old $\times \mathrm{P}$ & 8.95 & 96.5 & 0.0 & - \\
\hline B x 50 days old $\times P$ & 9.45 & 101.9 & 0.5 & - \\
\hline $\mathrm{C} \times 50$ days old $\times \mathrm{P}$ & 8.80 & 96.6 & -0.15 & - \\
\hline A x 50 days old $\times \mathrm{Pe}$ & 7.70 & 98.3 & -1.25 & 0 \\
\hline B x 50 days old $\times \mathrm{Pe}$ & 11.05 & 114.3 & 2.1 & $*$ \\
\hline C x 50 days old $\times \mathrm{Pe}$ & 9.45 & 173.6 & 0.5 & - \\
\hline A x 50 days old $\times \mathrm{P}+\mathrm{Pe}$ & 8.75 & 164.5 & -0.2 & - \\
\hline B x 50 days old $\times \mathrm{P}+\mathrm{Pe}$ & 10.10 & 168.3 & 1.15 & $*$ \\
\hline $\mathrm{C} \times 50$ days old $\times \mathrm{P}+\mathrm{Pe}$ & 10.25 & 149.2 & 1.30 & $*$ \\
\hline A x 50 days old $\times P+P e+M$ & 8.25 & 130.3 & -0.7 & - \\
\hline B x 50 days old $\times P+P e+M$ & 10.95 & 141.4 & 2.0 & $*$ \\
\hline $\mathrm{C} \times 50$ days old $\times \mathrm{P}+\mathrm{Pe}+\mathrm{M}$ & 10.35 & 115.6 & 1.4 & $*$ \\
\hline Mean of experience (C) & 8.95 & 100.0 & 00.0 & - \\
\hline DL (p 5\%) & & & 1.14 & \\
\hline DL (p 1\%) & & & 2.26 & \\
\hline DL (p $0,1 \%)$ & & & 3.37 & \\
\hline
\end{tabular}


cuttings of 30 days. It is observed that the root system, in the variants examined, has a better development in average temperatures between 22 to $22.5^{\circ} \mathrm{C}$. Above temperatures of $23.5^{\circ} \mathrm{C}$, the analyzed variants show a decrease in the root system. The optimal development of the root system is situated between 40000-45000 lux, below and above these values the light intensity has a negative influence on the growth of roots, expressed in lengths between $6.9-7-3 \mathrm{~cm}$.

The influence of exogenous factors on rooting cuttings of 50 days presents a different pattern as compared to the cuttings of 30 days. From the graphical presentation (Figure 2) it can be noticed that the cuttings of 50 days rooted better at temperatures exceeding $23^{\circ} \mathrm{C}$. It has been noticed a decrease of the root system when the temperature drops. In the temperature range of $20.5-22.5^{\circ} \mathrm{C}$ the experimental variations show roots between 6.9-7.3 cm.

The light intensity has a direct impact on the size of the root system. As light intensity increases, the size of the root system decreases and hence its development is also impacted. High values of root length are reached at a range of 30,000 to 40,000 lux.

The above data is confirmed by the values of the correlation coefficient in Table 5 . A statistically highly significant correlation was identified between the size of the root system and the temperature of the rooting substrate in the cuttings of 50 days. Another positive correlation was recorded between the length of the root system and the type of the rooting substrate.
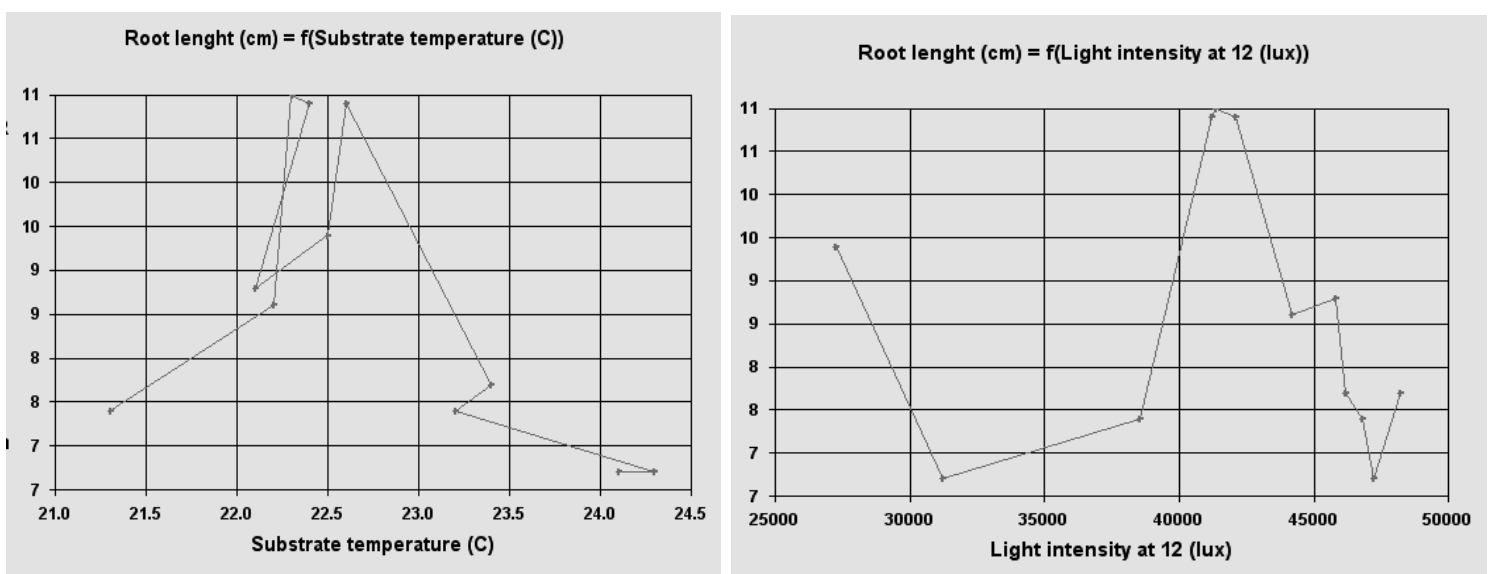

Fig.1. Interaction between root length $(\mathrm{cm})$ and substrate temperature $\left({ }^{\circ} \mathrm{C}\right)$, light intensity (lux), respectively at 30 days cuttings
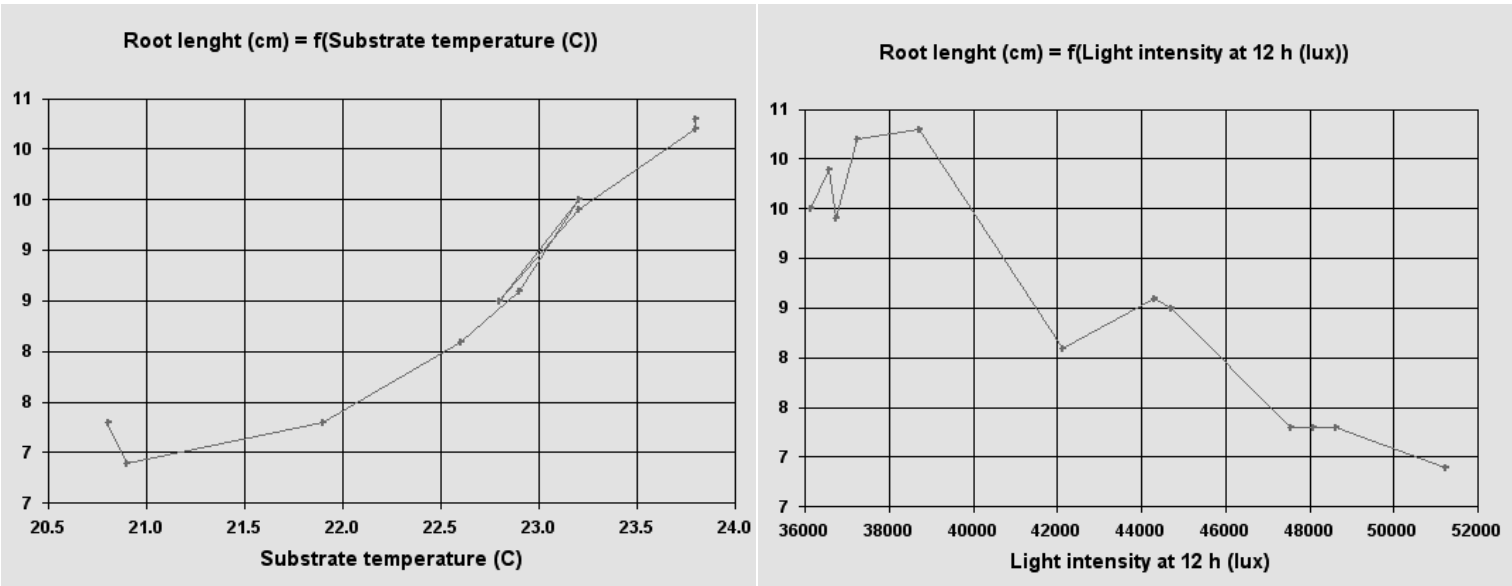

Fig. 2. Interaction between root length $(\mathrm{cm})$ and substrate temperature $\left({ }^{\circ} \mathrm{C}\right)$, light intensity (lux), respectively at 50 days cuttings 
Tab. 5. The correlation coefficient (r) of three experimental factor correlated

\begin{tabular}{|c|c|c|c|}
\hline \multirow[b]{2}{*}{ No. crt } & \multirow[b]{2}{*}{ Experimental variants } & \multicolumn{2}{|c|}{$r$ value for correlated factors } \\
\hline & & $\begin{array}{l}\text { Root length } \mathrm{x} \\
\text { temperature }\end{array}$ & $\begin{array}{l}\text { Root length } \mathrm{x} \text { light } \\
\text { intensity }\end{array}$ \\
\hline \multicolumn{4}{|c|}{ Genotype } \\
\hline 1. & A & 0.11 & $-0.91^{\circ}$ \\
\hline 2. & $\mathrm{~B}$ & 0.32 & -0.75 \\
\hline 3. & $\mathrm{C}$ & 0.13 & -0.49 \\
\hline \multicolumn{4}{|c|}{ Cutting type } \\
\hline 1. & 30 days & 0.31 & -0.38 \\
\hline 2. & 50 days & $0.69 *$ & $0.92^{* * *}$ \\
\hline \multicolumn{4}{|c|}{ Rooting substrate } \\
\hline 1. & Peat & 0.70 & $-0.86^{\circ}$ \\
\hline 2. & Perlite & $-0.81^{\circ}$ & -0.61 \\
\hline 3. & Peat+perlite & 0.77 & $-0.86^{\circ}$ \\
\hline 4. & Peat+perlite+manure & $0.83^{*}$ & -0.18 \\
\hline
\end{tabular}

Notes: genotype $\mathrm{n} 1=6$ cases P $5 \%=0,81, \mathrm{P} 1 \%=0,92$; cutting type $\mathrm{n} 2=8$ cases, P $5 \%=0,58, \mathrm{P} 1 \%=0,71 ;$ substrates $\mathrm{n} 3=12$ cases P $5 \%=0,81$, $\mathrm{P} 1 \%=0,92$

It has been noticed a series of negative correlation between the size of the root system and the light intensity in all experimental variants.

\section{CONCLUSIONS AND RECOMMENDATIONS}

The results obtained as a result of vegetative propagation using Gloxinia leaves cuttings allow us to draw some relevant conclusions and recommendations:

1. The genotypes of Gloxinia analyzed lend themselves to vegetative propagation through leaves cuttings. The B Genotype responded the best to the rooting process.

2. The degree of the rooting cuttings was based on the analyzed exogenous factors and the type of substrate used. Moreover the age of cutting is highly important. The cuttings of 50 days have a better capacity to issue adventitious roots than the cuttings of 30 days.

3. The optimal temperature of the rooting substrate is between 22 to $22.5^{\circ} \mathrm{C}$ in cuttings of 30 days, and the cuttings of 50 days root favorably in temperatures between 23.0 to $23.5{ }^{\circ} \mathrm{C}$. 4. The optimal development of the root system is carried out at a light intensity between 40000-45000 lux in cuttings of 30 days and in cuttings of 50 days the range is between 30000-40000 lux.
5. There is a positive correlation between the size of the root system and the temperature of the rooting substrate. Of notice are also the negative correlations between the length of the root system and the light intensity depending on the age of cuttings used.

6. Out of the substrates examined, the mixture of peat + perlite + manure leads to a high degree of rooting and to the development of a vigorously root system.

Recommendations:

1. Use B genotype for vegetative propagation of Gloxinia.

2. For better rooting, it is recommended that the optimal level of exogenous factors (temperature and light intensity) is respected.

3. Peat and perlite substrates, used alone, and in combination are not conducive to Gloxinia genotypes studied.

Acknowledgements. This paper was published under the frame of European Social Fund, Human Resources Development Operational Programme 2007-2013, projectno. POSDRU/159/1.5/S/132765.

\section{REFERENCES}

1. Buta E, Cantor M, Dumitraş A, Singureanu V, Moldovan G (2011). Influenţa substratului de înrădăcinare asupra procesului de multiplicare a butaşilor de Gloxinia speciosa, Revista Botanică, nr. 3, vol. III, nr. 4, Chişinău, Rep. Moldova. 
2. Cantor M (2008). Plante ornamentale de interior. Ed Todesco Cluj.

3. Cervantes I (2010). Culture en intérieur, la bible du jardinage indoor. Master Edition, Mama Editions, Paris, France.

4. Draghia L, Chelariu EL (2011). Floricultură. Ed. Ion Ionescu de la Brad Iaşi.
5. Toogood A (1999). AHS - Plant propagation: The fully illustrated plant-by-plant manual of practical techniques. DK Publishing Inc, US, New York, p. 277.

6. Toma F (2009). Floricultură şi artă florală. Vol. I-V. Invel Multimedia Publishing House, Bucharest.

7. Verdan MH, Armando CC, Francinete RC, Andersson B, Maria E, Stefanello A (2009). Anthraquinones and ethylcyclohexane derivatives from Sinningia speciosa "Fyfiana". Biochem Syst Ecol 37:40-42. 